\title{
Kinetics of Pitting Dissolution of Austenitic Stainless Steel 304 in Sodium Chloride Solution
}

\author{
M. Saadawy \\ Chemistry Department, Faculty of Science, Alexandria University, Ibrahimia, P.O. Box 426, Alexandria 21321, Egypt
}

Correspondence should be addressed to M. Saadawy, mw169@yahoo.com

Received 26 July 2012; Accepted 6 September 2012

Academic Editors: S. Umoren and R. Wang

Copyright () 2012 M. Saadawy. This is an open access article distributed under the Creative Commons Attribution License, which permits unrestricted use, distribution, and reproduction in any medium, provided the original work is properly cited.

The effect of addition of chloride ion on the corrosion of stainless steel 304 in $\mathrm{Na}_{2} \mathrm{SO}_{4}$ solution under constant ionic strength conditions at $30^{\circ} \mathrm{C}$ was studied using potential-time and potentiodynamic polarization techniques and it was found that the addition of chloride ion reduces the growth of protective passive film on the surface and increase corrosion current. The kinetics of dissolution in sodium chloride solution $(0.05-0.5 \mathrm{M})$ at $30^{\circ} \mathrm{C}$ was also studied and the kinetic rate equation was derived and was found to verify the following relationship: $V=k_{\text {obs }} C_{\mathrm{Cl}^{-}}$where $k_{\mathrm{obs}}=k\left(K_{1} K_{2} C_{\mathrm{H}_{2} \mathrm{O}} /\left(C_{\mathrm{H}^{+}}+K_{1} C_{\mathrm{H}^{+}} C_{\mathrm{H}_{2} \mathrm{O}}^{2}\right)\right) \sum \mathrm{Fe}$.

\section{Introduction}

Stainless steels are corrosion-resistant iron-base alloys containing a maximum of $1 \pm 2 \%$ carbon and a minimum of $10.5 \%$ chromium by weight, this is the minimum amount of chromium that prevents the formation of rust in humid unpolluted atmospheres, hence the designation "stainless". The high corrosion resistance of the stainless steel is attributable to the presence of thin and invisible passive film [1] characterized by stability, durability, adherence, and self-repairing. Austenitic stainless steels are an extraordinary family of stainless steel alloys that have exceptional corrosion resistance and equally impressive mechanical properties which allowed them to be used as a construction material in various aggressive environments such as heat exchanger systems, drilling platforms, wastewater treatment, and desalination plants. Factors contributing to their increased use are their long service life with low maintenance cost, ability to be recycled, and benign effect on the environment and human health. Although austenitic stainless steels show a very high corrosion resistance in many aggressive environments, they can suffer pitting corrosion in chloride environments [2]. The aggressiveness and ability of $\mathrm{Cl}^{-}$ions to initiate pitting are well known [3-5]. The most popular austenitic grades have been type 304 (containing 18\% chromium, $8 \%$ nickel and also known by the UNS Number S30400). The pitting mechanism of passive 304 stainless steel (or 304 SS) in 3.5\% $\mathrm{NaCl}[6]$ and in sulphuric acid media containing chloride ions [7] has been investigated. The aim of the present work is to study the kinetics of dissolution of 304 SS in sodium chloride solution $(0.05-0.5 \mathrm{M})$ at $30^{\circ} \mathrm{C}$.

\section{Experimental}

Potential-time and potentiodynamic polarization measurements were achieved using frequency response analyzer Gill $\mathrm{AC}$ instrument. Polarization measurements were carried out at scan rate of $30 \mathrm{mV} / \mathrm{min}$. The measurements were done in an electrochemical cell with three-electrode mode; platinum sheet electrode and saturated calomel electrode (SCE) were used as counter and reference electrodes, respectively. The specimen used for constructing the working electrode was stainless steel 304 that had the chemical composition (weight \%) listed in Table 1.

The stainless steel samples were fixed in polytetrafluoroethylene (PTFE) rods by an epoxy resin in such a way that only one surface was left uncovered. The exposed area $\left(1 \mathrm{~cm}^{2}\right)$ was mechanically polished with a series of emery papers of variable grades, starting with a coarse one and proceeding in steps to the finest (800) grade. The samples were then washed thoroughly with double distilled water 
TABLE 1: Chemical composition of the specimen used for constructing the working electrode.

\begin{tabular}{lcccccccccccc}
\hline Element & $\mathrm{Fe}$ & $\mathrm{Cr}$ & $\mathrm{Ni}$ & $\mathrm{Mn}$ & $\mathrm{Mo}$ & $\mathrm{Ti}$ & $\mathrm{Al}$ & $\mathrm{V}$ & $\mathrm{S}$ & $\mathrm{C}$ & $\mathrm{Cu}$ \\
\hline $\mathrm{Wt} \%$ & 71.075 & 18.25 & 8.5 & 0.58 & 1.17 & 0.06 & 0.02 & 0.06 & 0.005 & 0.17 & 0.11 & \\
\hline
\end{tabular}

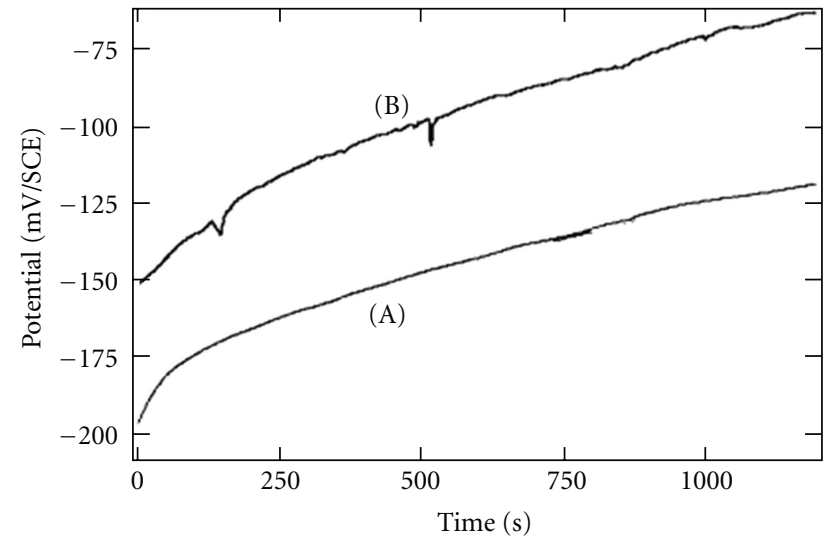

FIgure 1: The open circuit potential (OCP) of $304 \mathrm{SS}$ in (A) $0.5 \mathrm{M}$ $\mathrm{Na}_{2} \mathrm{SO}_{4}$, (B) $0.47 \mathrm{M} \mathrm{Na}_{2} \mathrm{SO}_{4}+0.1 \mathrm{M} \mathrm{NaCl}$ at $30^{\circ} \mathrm{C}$.

followed with A.R. ethanol and finally with distilled water, just before insertion in the cell.

2.1. Solution Preparation. Solids: $\mathrm{NaCl}, \mathrm{Na}_{2} \mathrm{SO}_{4}$ are purchased from Aldrich Chemicals Company. The solutions were prepared using double distilled water. Stock solutions of $1 \mathrm{M} \mathrm{Na}_{2} \mathrm{SO}_{4}$ and $1 \mathrm{M} \mathrm{NaCl}$ solutions were used to prepare solutions containing $0.5 \mathrm{M} \mathrm{Na}_{2} \mathrm{SO}_{4}$ and the desired $\mathrm{NaCl}$ concentration using appropriate dilutions. The concentration of the stock solution was expressed in term of moles per $\mathrm{dm}^{3}$.

\section{Results and Discussion}

\subsection{Effect of Addition of Chloride Ion on the Corrosion Behav- iour of 304 SS in Sodium Sulphate Solution under Con- stant Ionic Strength Conditions at $30^{\circ} \mathrm{C}$}

3.1.1. Potential-Time Measurement. Figure 1 shows the open circuit potential (OCP) of $304 \mathrm{SS}$ in $0.5 \mathrm{M} \mathrm{Na}_{2} \mathrm{SO}_{4}$ solution and in $0.47 \mathrm{M} \mathrm{Na}_{2} \mathrm{SO}_{4}$ containing $0.1 \mathrm{M} \mathrm{NaCl}$ at $30^{\circ} \mathrm{C}$, both solutions have nearly the same ionic strength. It is evident that the OCP value is shifted to a more positive value when sodium chloride is added, it was reported [7] that this is an indication of breakdown of the protective passive film formed by sulphate ion due to addition of chloride ion since the adsorbed sulphate ions in some points are replaced by the less negative chloride ions.

3.1.2. Potentiodynamic Polarization Results. Figure 2 shows the potentiodynamic polarization curves for 304 SS in $0.5 \mathrm{M} \mathrm{Na}_{2} \mathrm{SO}_{4}$ solution and in $0.47 \mathrm{M} \mathrm{Na}_{2} \mathrm{SO}_{4}$ containing $0.1 \mathrm{M} \mathrm{NaCl}$ at $30^{\circ} \mathrm{C}$. These polarization curves can be divided into several potential domains [8]. The cathodic domain

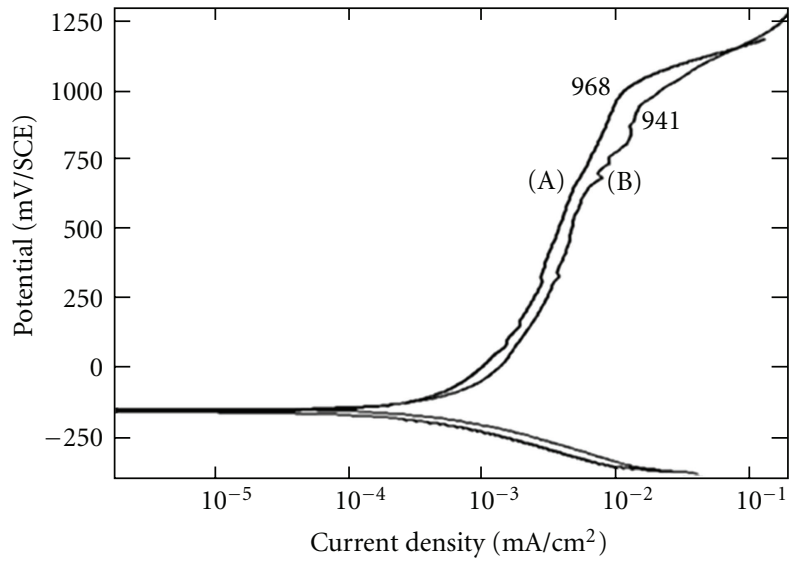

FIGURE 2: Potentiodynamic polarization curves of 304 SS in (A) $0.5 \mathrm{M} \mathrm{Na}_{2} \mathrm{SO}_{4}$, (B) $0.47 \mathrm{M} \mathrm{Na}_{2} \mathrm{SO}_{4}+0.1 \mathrm{M} \mathrm{NaCl}$ at $30^{\circ} \mathrm{C}$.

includes potentials below the corrosion potential, where current density determined by the cathodic reaction shows a continuous increase in the current density of the cathodic branch as the potential decreases, shifting these cathodic branches to greater current densities as $\mathrm{NaCl}$ is added. The next potential domain corresponds to the cathodic-anodic transition, this domain is characterized by the corrosion potential and the corrosion current density. The third domain corresponds to the anodic domain region which can be divided into three parts, in the first part, the current increases graphically followed by a small quasi-passive region in which current increases slowly due to the formation of small passive film in presence of $\mathrm{Na}_{2} \mathrm{SO}_{4}$, this passive film breaks at certain critical potential, breakdown potential or $E_{b}=968 \mathrm{mV}$ at which current returns to increase quickly in the third part of anodic domain region, this breakdown potential changes to more negative value, $941 \mathrm{mV}$, when sodium chloride is added, this means that breakdown of passive film takes place earlier in the presence of chloride ion and a higher driving force is required to keep the passive film in the presence of chloride ion.

Pistorius and Burstein [9] found that the relative solubility of metal cations in pit solution increases as $\mathrm{Cl}^{-} / \mathrm{SO}_{4}{ }^{-2}$ ratio increases which results in the increasing of saturation solubility of metal cations and increasing dissolution rate. It is reported [10] that the propagation rate of pits in depth and width is the highest at $\mathrm{Cl}^{-} / \mathrm{SO}^{-2}=0.75$.

The corrosion current density, $i_{\text {corr }}$, was calculated from the intersection of cathodic and anodic Tafel lines and the values of the electrochemical parameters: corrosion potential, $E_{\text {corr }}$, corrosion current density, $i_{\text {corr }}$, and anodic and cathodic Tafel slopes, $\beta_{\mathrm{a}}, \beta_{\mathrm{c}}$ for the last two solutions are shown in Table 2. 
TABLE 2: Electrochemical polarization parameters of Stainless steel 304.

\begin{tabular}{lcccc}
\hline Solution & $-E_{\text {corr }}(\mathrm{mV} / \mathrm{SCE})$ & $\beta_{\mathrm{a}}(\mathrm{mV} /$ decade $)$ & $\beta_{\mathrm{c}}(\mathrm{mV} /$ decade $)$ & $i_{\text {corr }}\left(\mathrm{mA} / \mathrm{cm}^{2}\right)$ \\
\hline $0.5 \mathrm{M} \mathrm{Na}_{2} \mathrm{SO}_{4}$ & 167 & 173.1 & 91.5 & $1.5 \times 10^{-5}$ \\
$0.47 \mathrm{M} \mathrm{Na}_{2} \mathrm{SO}_{4}+0.1 \mathrm{M} \mathrm{NaCl}$ & 150 & 182.5 & 107.5 & $2.8 \times 10^{-5}$ \\
\hline
\end{tabular}

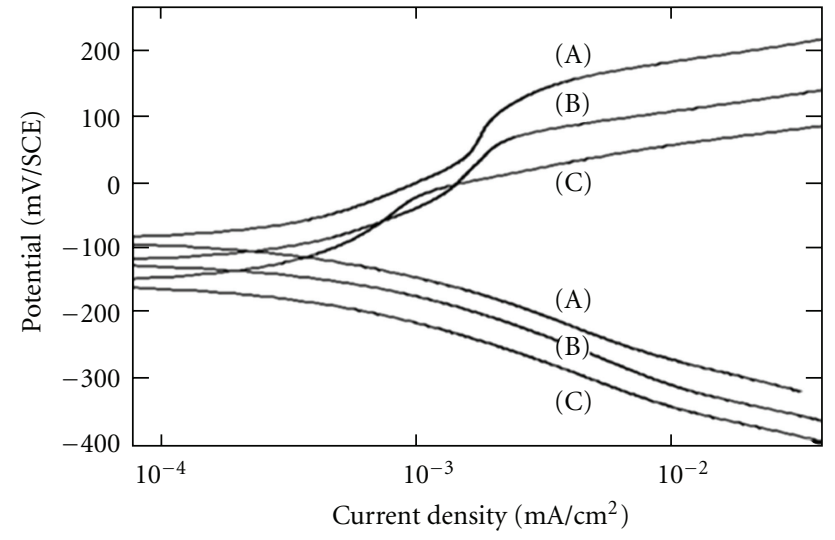

Figure 3: Potentiodynamic polarization curves of 304 SS in (A) $0.1 \mathrm{M} \mathrm{NaCl}$, (B) $0.3 \mathrm{M} \mathrm{NaCl},(\mathrm{C}) 0.5 \mathrm{M} \mathrm{NaCl}$ at $30^{\circ} \mathrm{C}$.

It is clear from Table 2 that in presence of $\mathrm{Cl}^{-}, E_{\text {corr }}$ goes to more positive values and $i_{\text {corr }}$ increases although ionic strength is constant due to incorporation of chloride ion in the passive film while Tafel slopes, $\beta_{\mathrm{a}}, \beta_{\mathrm{c}}$ are not significantly changed indicating the same dissolution mechanism [1113].

3.2. Effect of Concentration of $\mathrm{NaCl}$ on the Polarization Behaviour of 304 SS. Figure 3 shows the potentiodynamic polarization curves for $304 \mathrm{SS}$ in $\mathrm{NaCl}$ solutions of different concentrations at $30^{\circ} \mathrm{C}$, it is clear that increasing the concentration of $\mathrm{NaCl}$ affects both anodic and cathodic parts of polarization curve, shifts it to greater values of $i_{\text {corr }}$, and shifts $E_{\text {corr }}$ to more negative values due to the adsorption of negative chloride ions. At the pitting or breakdown potential, $E_{b}$ current increases suddenly due to breakdown of passive film. According to the literature, the pitting potential represents the potential limit above which the formation of pitting begins [14]. The more negative the value of pitting potential is, the less resistant the metal is to pit initiation and the shorter the time required for pit initiation at potentials below $E_{b}$ is, that is, $E_{b}$ shifts to smaller (more negative) values with increasing chloride ion concentration.

It is reported $[15,16]$ that the breakdown (pitting) potential $\left(E_{\mathrm{b}}\right)$ shows logarithmic dependence on chloride ion concentration $\left(C_{\mathrm{c}^{-}}\right)$of the form:

$$
E_{b}=\mathrm{A}-\mathrm{B} \log C_{\mathrm{cl}^{-}},
$$

where $\mathrm{A}$ and $\mathrm{B}$ are constants and depend on the type of metal and corrosive medium.

3.3. Kinetics of the Corrosion of $304 \mathrm{SS}$ in $\mathrm{NaCl}$ Solution. In a previous work [17] It was revealed that the passive film on stainless steel 304 exists mainly in the form $\mathrm{H}_{2} \mathrm{O}-$ $\mathrm{Fe}-\mathrm{H}_{2} \mathrm{O}$ and that chloride ions adsorb at certain points on the the surface forming an intermediate complex [7] which causes rapid dissolution of the passive film to take place at these points which leads to pit nucleation. When the pit nucleus attains a critical size, crystal growth takes place stably in these positions. In most areas in which no $\mathrm{Cl}^{-}$is adsorbed, passivation reactions still take place. We thus propose a mechanism in which chloride ion forms an intermediate complex with the passive metal followed by successive dissolution. This type of mechanism is given by the following series of steps:

$$
\mathrm{Fe}+2 \mathrm{H}_{2} \mathrm{O} \stackrel{k 1}{\longleftrightarrow} \mathrm{Fe}\left(\mathrm{H}_{2} \mathrm{O}\right)_{2}
$$

$$
\mathrm{Fe}\left(\mathrm{H}_{2} \mathrm{O}\right)_{2}+\mathrm{Cl}^{-} \stackrel{k 2}{\longrightarrow}\left(\mathrm{FeOHCl}^{-}\right)_{\mathrm{ads}}+\mathrm{H}_{2} \mathrm{O}+\mathrm{H}^{+}+\mathrm{e}^{-}
$$

$$
\begin{gathered}
\left(\mathrm{FeOHCl}^{-}\right)_{\text {ads }} \stackrel{\text { slow }}{\longrightarrow}(\mathrm{FeOHCl})_{\text {comp }}+\mathrm{e}^{-} \\
(\mathrm{FeOHCl})_{\text {comp }}+n \mathrm{Cl}^{-} \stackrel{\text { fast }}{\longrightarrow}\left[\mathrm{Fe}(\mathrm{OH}) \mathrm{Cl}_{(n+1)}\right]^{-n} \\
{\left[\mathrm{Fe}(\mathrm{OH}) \mathrm{Cl}_{(n+1)}\right]^{-n}} \\
+\mathrm{H}^{+} \stackrel{\text { fast }}{\longrightarrow} \mathrm{Fe}_{\text {sol }}^{2+} \\
+\mathrm{H}_{2} \mathrm{O}+(n+1) \mathrm{Cl}^{-}
\end{gathered}
$$

This proposed mechanism is used to derive the kinetic rate equation for the dissolution of $304 \mathrm{SS}$ in sodium chloride solution (see the Appendix). The dependence of the rate of pitting corrosion on chloride ion was found to take the form:

$$
V=k_{\mathrm{obs}} C_{\mathrm{cl}^{-}} \text {where } k_{\mathrm{obs}}=k \frac{K_{1} K_{2} C_{\mathrm{H}_{2} \mathrm{O}}}{C_{\mathrm{H}^{+}}+K_{1} C_{\mathrm{H}^{+}} C^{2} \mathrm{H}_{2} \mathrm{O}} \sum \mathrm{Fe} \text {. }
$$

Application of the kinetic rate equation to polarization data of $304 \mathrm{SS}$ in $\mathrm{NaCl}$ solutions.

The corrosion rate, $V$, in mils per year for the dissolution of metal is related to the corrosion current density, $i_{\text {corr }}$, using the formula [16]:

$$
\text { corrosion rate }(V)=\frac{\text { metalfactor }^{*} i_{\text {corr }}}{25.4} \text {. }
$$

So the values of $i_{\text {corr }}$ can be taken as a measure of the corrosion rate, $V$.

Figure 4 shows the linear fit of $i_{\text {corr }}$ versus concentration of chloride ion at $30^{\circ} \mathrm{C}$ according to (7), this is a good support of the last proposed mechanism.

\section{Conclusions}

Mechanism of pitting corrosion of stainless steel 304 in sodium chloride solution involves the formation of an 


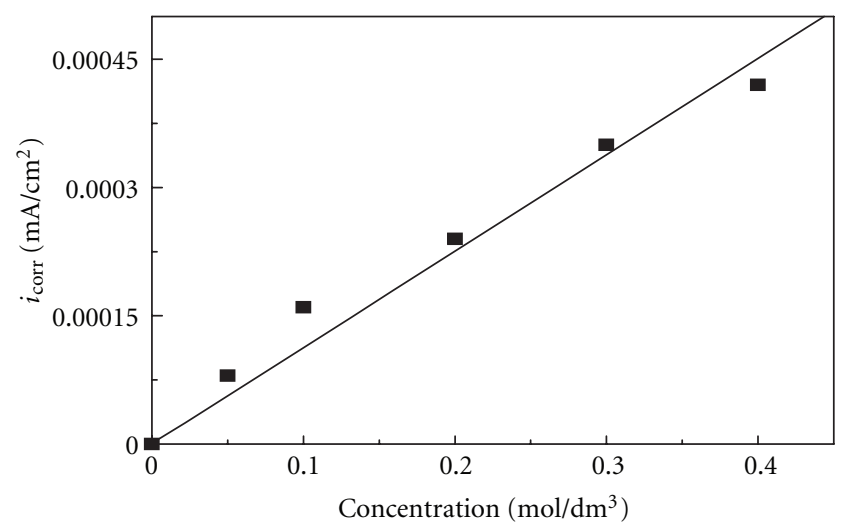

Figure 4: Linear fit of corrosion current values of 304 SS with concentration of $\mathrm{NaCl}$ solution according to the proposed mechanism at $30^{\circ} \mathrm{C}$.

intermediate complex of chloride ion with the passive metal followed by successive dissolution.

\section{Appendix}

$$
\begin{gathered}
\mathrm{Fe}+2 \mathrm{H}_{2} \mathrm{O} \stackrel{\mathrm{kl}}{\longleftrightarrow} \mathrm{Fe}\left(\mathrm{H}_{2} \mathrm{O}\right)_{2} \\
\mathrm{Fe}\left(\mathrm{H}_{2} \mathrm{O}\right)_{2}+\mathrm{Cl}^{-} \stackrel{\mathrm{k} 2}{\longleftrightarrow}\left(\mathrm{FeOHCl}^{-}\right)_{\mathrm{ads}}+\mathrm{H}_{2} \mathrm{O}+\mathrm{H}^{+}+\mathrm{e}^{-}
\end{gathered}
$$$$
\left(\mathrm{FeOHCl}^{-}\right)_{\mathrm{ads}} \stackrel{\text { slow }}{\longrightarrow}(\mathrm{FeOHCl})_{\mathrm{comp}}+\mathrm{e}^{-}
$$$$
(\mathrm{FeOHCl})_{\text {comp }}+n \mathrm{Cl}^{-} \stackrel{\text { fast }}{\longrightarrow}\left[\mathrm{Fe}(\mathrm{OH}) \mathrm{Cl}_{(n+1)}\right]
$$

$$
\left[\mathrm{Fe}(\mathrm{OH}) \mathrm{Cl}_{(n+1)}\right]+\mathrm{H}^{+} \stackrel{\text { fast }}{\longrightarrow} \mathrm{Fe}_{\text {sol }}^{2+}+\mathrm{H}_{2} \mathrm{O}+(n+1) \mathrm{Cl}^{-}
$$

The derivation of the kinetic rate equation from the sequence of reaction steps (A.1) to (A.5) as follows:

$$
\begin{gathered}
\text { rate }(\mathrm{V})=k C_{\mathrm{Fe}(\mathrm{OH}) \mathrm{Cl}^{-},} \\
\sum \mathrm{Fe}=C_{\mathrm{Fe}}+C_{\mathrm{Fe}(\mathrm{H} 2 \mathrm{O}) 2}+C_{\mathrm{Fe}(\mathrm{OH}) \mathrm{Cl}^{-}}
\end{gathered}
$$

From (A.1)

$$
K_{1}=\frac{C_{\mathrm{Fe}\left(\mathrm{H}_{2} \mathrm{O}\right)_{2}}}{C_{\mathrm{Fe}} \mathrm{C}^{2} \mathrm{H}_{2} \mathrm{O}}
$$

From (A.2)

$$
K_{2}=\frac{C_{\mathrm{H}^{+}} C_{\mathrm{H}_{2} \mathrm{O}} C_{\mathrm{Fe}(\mathrm{OH}) \mathrm{Cl}^{-}}}{C_{\mathrm{Fe}\left(\mathrm{H}_{2} \mathrm{O}\right)_{2}} C_{\mathrm{Cl}^{-}}}
$$

Therefore

$$
K_{1} K_{2}=\frac{C_{\mathrm{H}^{+}} C_{\mathrm{Fe}(\mathrm{OH}) \mathrm{Cl}^{-}}}{C_{\mathrm{Fe}} C_{\mathrm{Cl}^{-}} C_{\mathrm{H}_{2} \mathrm{O}}}
$$

From (A.9) and (A.10)

$$
\begin{array}{r}
C_{\mathrm{Fe}(\mathrm{H} 2 \mathrm{O})_{2}}=\frac{C_{\mathrm{H}^{+}} C_{\mathrm{H}_{2} \mathrm{O}} C_{\mathrm{Fe}(\mathrm{OH}) \mathrm{Cl}^{-}}}{K_{2} C_{\mathrm{Cl}^{-}}}, \\
C_{\mathrm{Fe}}=\frac{C_{\mathrm{H}^{+}} C_{\mathrm{Fe}(\mathrm{OH}) \mathrm{Cl}^{-}}}{K_{1} K_{2} C_{\mathrm{H}_{2} \mathrm{O}} C_{\mathrm{Cl}^{-}}}
\end{array}
$$

Substitute from (A.11), (A.12) into (A.7)

$$
\begin{gathered}
\sum \mathrm{Fe}=C_{\mathrm{Fe}(\mathrm{OH}) \mathrm{Cl}^{-}}\left(\frac{C_{\mathrm{H}^{+}}}{K_{1} K_{2} C_{\mathrm{H}_{2} \mathrm{O}} C_{\mathrm{Cl}^{-}}}+\frac{C_{\mathrm{H}^{+}} C_{\mathrm{H}_{2} \mathrm{O}}}{K_{2} C_{\mathrm{Cl}^{-}}}+1\right), \\
\sum \mathrm{Fe}=C_{\mathrm{Fe}(\mathrm{OH}) \mathrm{Cl}^{-}}\left(\frac{C_{\mathrm{H}^{+}}+K_{1} C_{\mathrm{H}^{+}} C^{2} \mathrm{H}_{2} \mathrm{O}}{K_{1} K_{2} C_{\mathrm{H}_{2} \mathrm{O}} C_{\mathrm{Cl}^{-}} K_{2} C_{\mathrm{Cl}^{-}} C_{\mathrm{H}_{2} \mathrm{O}}}\right),
\end{gathered}
$$

$$
\text { or } \begin{aligned}
C_{\mathrm{Fe}(\mathrm{OH}) \mathrm{Cl}^{-}}= & \left(\frac{K_{1} K_{2} C_{\mathrm{H}_{2} \mathrm{O}} C_{\mathrm{Cl}^{-}}}{C_{\mathrm{H}^{+}}+K_{1} C_{\mathrm{H}^{+}} C^{2} \mathrm{H}_{2} \mathrm{O}+K_{1} K_{2} C_{\mathrm{Cl}^{-}} C_{\mathrm{H}_{2} \mathrm{O}}}\right) \\
& \times \sum \mathrm{Fe} .
\end{aligned}
$$

Introduce into rate (A.6):

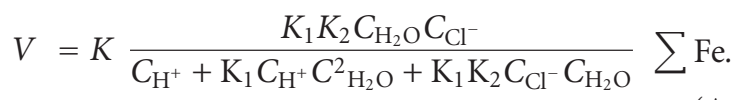

At the condition that $C_{\mathrm{H}^{+}}+K_{1} C_{\mathrm{H}^{+}} C^{2} \mathrm{H}_{2} \mathrm{O} \gg K_{1} K_{2} C_{\mathrm{Cl}^{-}}$ $C_{\mathrm{H}_{2} \mathrm{O}}$ so last equation becomes

\section{Acknowledgments}

The author wishes to thank Professor Dr. Beshir Ahmed Abd El-Nabey and Prof. Dr. Ashraf Moustafa, Department of Chemistry, Faculty of Science, Alexandria University, Alexandria, Egypt for continuous support and providing advanced instruments.

\section{References}

[1] J. Sedriks, Corrosion of Stainless Steels, John Wiley \& Sons, New York, NY, USA, 2nd edition, 1996.

[2] A. Fossati, F. Borgioli, E. Galvanetto, and T. Bacci, "Corrosion resistance properties of glow-discharge nitrided AISI 316L austenitic stainless steel in $\mathrm{NaCl}$ solutions," Corrosion Science, vol. 48, no. 6, pp. 1513-1527, 2006.

[3] Q. Yang and J. L. Luo, "Effects of hydrogen and tensile stress on the breakdown of passive films on type 304 stainless steel," Electrochimica Acta, vol. 46, pp. 851-859, 2001.

[4] E. A. Abd El Meguid, N. A. Mahmoud, and S. S. Abd El Rehim, "Effect of some sulphur compounds on the pitting corrosion of type 304 stainless steel," Materials Chemistry and Physics, vol. 63 , no. 1 , pp. 67-74, 2000.

[5] S. S. El-Egamy and W. A. Badway, "Passivity and passivity breakdown of 304 stainless steel in alkaline sodium sulphate solutions," Journal of Applied Electrochemistry, vol. 34, no. 11, pp. 1153-1158, 2004.

[6] R. Wang and M. Kido, "Influence of input power to vibrator and vibrator-to-specimen distance of ultrasound on pitting corrosion of SUS304 stainless steel in 3.5\% chloride sodium aqueous solution," Corrosion Science, vol. 51, no. 8, pp. 16041610, 2009.

[7] P. Q. Zhang, J. X. Wu, W. Q. Zhang, X. Y. Lu, and K. Wang, "A pitting mechanism for passive 304 stainless steel in sulphuric acid media containing chloride ions," Corrosion Science, vol. 34, no. 8, pp. 1343-1349, 1993. 
[8] E. Blasco-Tamarit, D. M. Garcia-Garcia, and J. Garcia Anton, "Imposed potential measurements to evaluate the pitting corrosion resistance and the galvanic behaviour of a highly alloyed austenitic stainless steel and its weldment in a $\mathrm{LiBr}$ solution at temperatures up to $150{ }^{\circ} \mathrm{C}$," Corrosion Science, vol. 53, no. 2, pp. 784-795, 2011.

[9] P. C. Pistorius and G. T. Burstein, "Growth of corrosion pits on stainless steel in chloride solution containing dilute sulphate," Corrosion Science, vol. 33, pp. 1885-1897, 1992.

[10] Yu. Zuo, H. Wang, J. Zhao, and J. Xiong, "The effects of some anions on metastable pitting of 316L stainless steel," Corrosion Science, vol. 44, pp. 13-24, 2002.

[11] A. M. Abdel-Gaber, B. A. Abd-El-Nabey, and M. Saadawy, "The role of acid anion on the inhibition of the acidic corrosion of steel by lupine extract," Corrosion Science, vol. 51, no. 5, pp. 1038-1042, 2009.

[12] A. M. Abdel-Gaber, B. A. Abd-El-Nabey, I. M. Sidahmed, A. M. El-Zayady, and M. Saadawy, "Inhibitive action of some plant extracts on the corrosion of steel in acidic media," Corrosion Science, vol. 48, no. 9, pp. 2765-2779, 2006.

[13] A. M. Abdel-Gaber, B. A. Abd-El Nabey, I. M. Sidahmed, A. M. El-Zayady, and M. Saadawy, "Effect of temperature on inhibitive action of damsissa extract on the corrosion of steel in acidic media," Corrosion, vol. 62, no. 4, pp. 293-299, 2006.

[14] A. Pardo, E. Otero, M. C. Merino, M. D. López, M. V. Utrilla, and $\mathrm{F}$. Moreno, "Influence of $\mathrm{pH}$ and chloride concentration on the pitting and crevice corrosion behavior of high-alloy stainless steels," Corrosion, vol. 56, no. 4, pp. 411-418, 2000.

[15] J. R. Galvele, "Transport processes and the mechanism of pitting of metals," Journal of the Electrochemical Society, vol. 123 , no. 4, pp. 464-474, 1976.

[16] A. M. Abdel-Gaber, B. A. Abd-El-Nabey, I. M. Sidahmed, A. M. El-Zayady, and M. Saadawy, "Kinetics and thermodynamics of aluminium dissolution in $1.0 \mathrm{M}$ sulphuric acid containing chloride ions," Materials Chemistry and Physics, vol. 98, no. 2-3, pp. 291-297, 2006.

[17] G. Okamoto and T. Shibata, "Stability of passive stainless steel in relation to the potential of passivation treatment," Corrosion Science, vol. 10, pp. 371-378, 1970. 

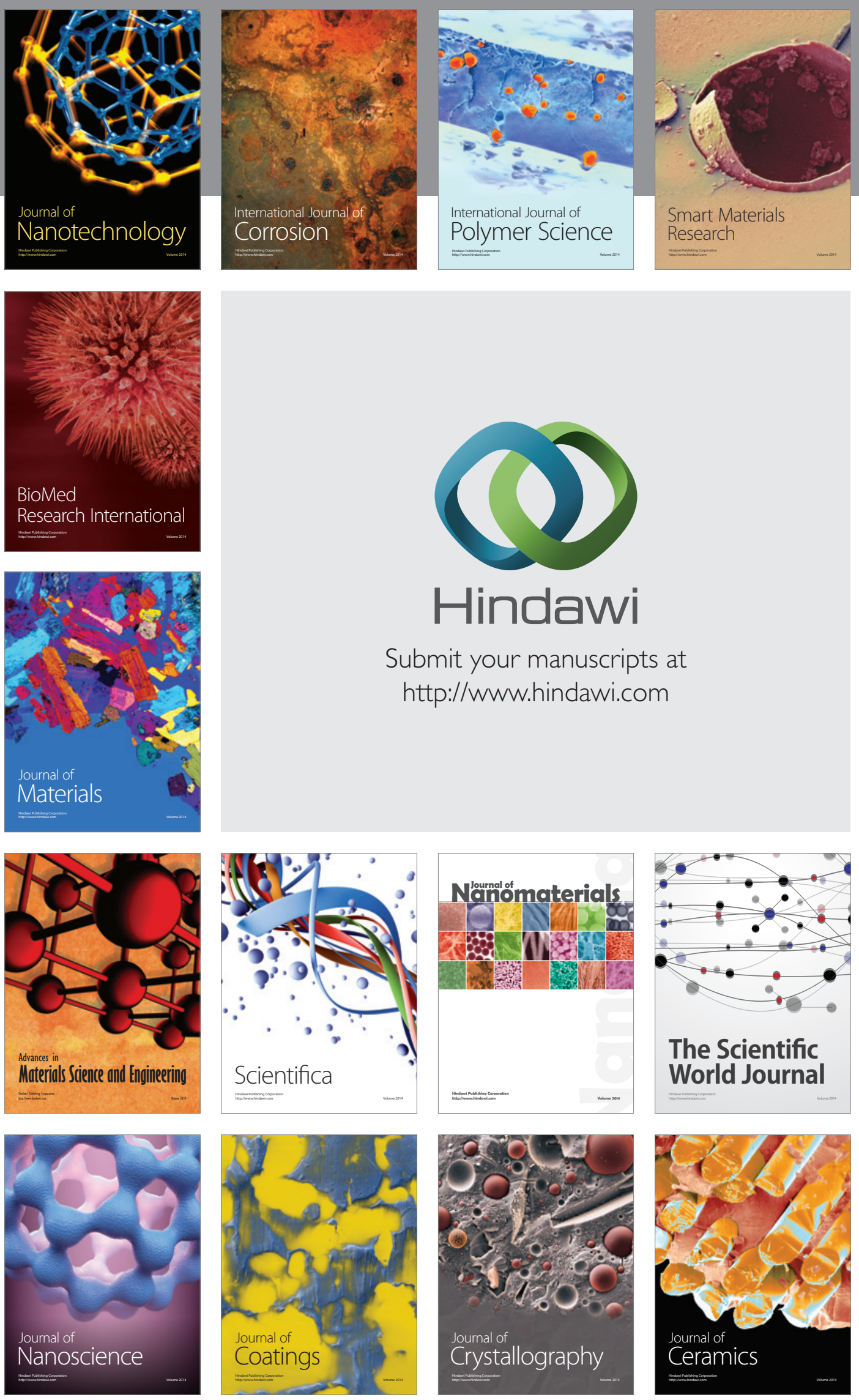

The Scientific World Journal

Submit your manuscripts at

http://www.hindawi.com

\section{World Journal}

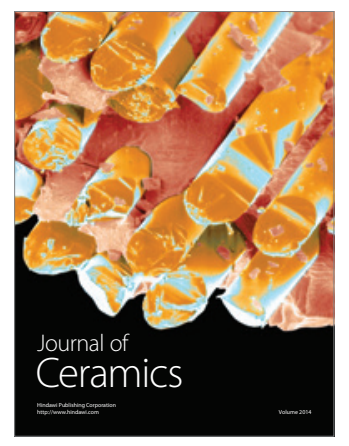

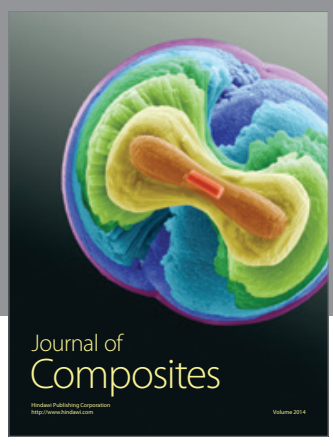
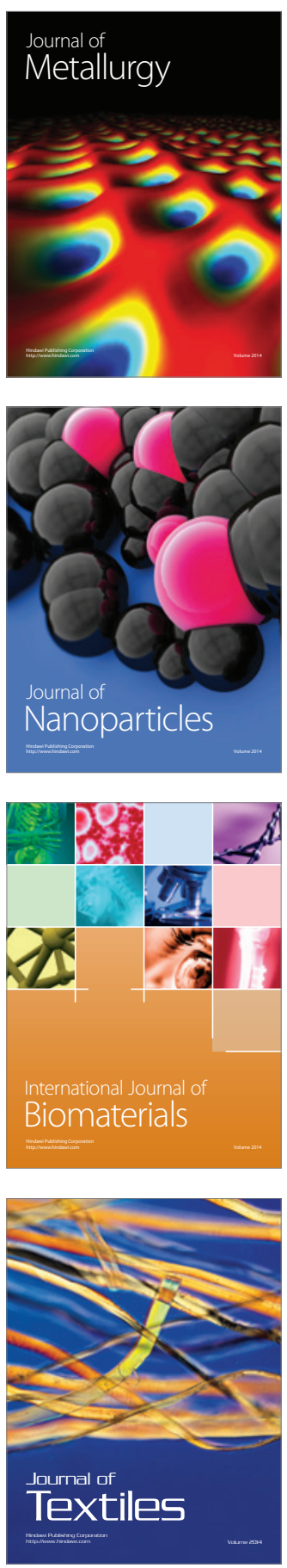